\title{
A Theoretical Framework For Managing CSR Plans And Related Initiatives In The Modern Business Environment
}

Estelle van Tonder, Milpark Business School, South Africa

Mornay Roberts-Lombard, University of Johannesburg, South Africa

\begin{abstract}
Organisations can make a valuable contribution in alleviating poverty and improving the general living standards of society. In the modern turbulent business environment, characterised by intense competition and customers demanding corporate responsibility, it further seems that a well-managed corporate social responsibility (CSR) plan could assist executives in winning the hearts and minds of their customers. Regular interactions with stakeholders on CSR initiatives can also assist executives in identifying trends in the market and introducing innovations. CSR can further be used as a strategic tool to manage the reputation of the organisation. Consequently, the purpose of this paper is to provide a theoretical framework on guidelines that organisations could implement to manage their CSR plans and CSR-related initiatives more effectively. A number of secondary sources, including textbooks and previous research studies, were consulted in compiling the proposed framework which includes actions that executives could take to design and implement their CSR plans more effectively. In addition, principles for the effective management of CSR-driven innovations and reputation management initiatives are also provided. The framework also focuses on guidelines for the types of social media initiatives that would need to be incorporated into the executive's strategic plan to ensure that the strategy implemented is truly competitive. The paper concludes with a number of recommendations that could be further investigated in a follow-on empirical study to provide further assistance to organisations wishing to survive and grow their businesses in the modern turbulent business environment. The paper is relevant to executives requiring guidance on implementing their CSR initiatives more successfully and contributes to the improvement of organisational behaviour within the socially responsible environment.
\end{abstract}

Keywords: Corporate Social Responsibility; Innovation; Reputation Management; Social Media

\section{INTRODUCTION AND BACKGROUND}

¿

$\mathrm{n}$ the modern era, in which market and industry boundaries can no longer be easily defined, executives are confronted with many complex and challenging problems. New and disruptive forms of competition are emerging, customers have greater insight and demands, and many individuals have become activists placing pressure on organisations to follow high ethical standards and take care of their corporate responsibility. In this turbulent business environment executives are left with no alternative but to investigate new sources of competitive advantage (Cravens \& Piercy, 2013, p. 227).

Correspondingly, many large corporations have started introducing new socially responsible initiatives in an attempt to convince stakeholders that they are caring about the world (Cravens \& Piercy, 2013, p. 2). This trend is seen as one of the most important corporate developments since the start of the new millennium (Barnea \& Rubin, 2005 , p. 1). The notion of corporate social responsibility (CSR) is growing in meaning and significance (Carroll \& Shabana, 2010, p. 85). It has advanced and progressed in both academic and practitioner societies worldwide. Organisations following this trend are in support of the new marketing discipline, Marketing 3.0 (as identified by 
marketing guru, Phillip Kotler), which reflects values that amount to being concerned about the state of the planet (Cravens \& Piercy, 2013, p. 2).

Organisations can benefit greatly from social responsible initiatives, as increasingly customers prefer organisations that endorse positive societal change (Cravens \& Piercy, 2013, p. 2). A further advantage is that organisations can also use CSR initiatives as a "radar" to identify trends in the market and introduce innovations. Louw and Venter (2012, pp. 62-63) explain that regular interactions with stakeholders will enable the organisation to anticipate and respond to regulatory, economic and social changes in the environment, and stakeholders can provide ideas for new products, processes and markets that can assist the organisation in obtaining a competitive advantage.

Corporate social responsibility can also be used as a strategic tool to manage the reputation of the organisation (Jacob, 2012, p. 263). Perceptions of the organisation's interactions (as a good citizen) with communities, employees and the environment are considered as an important criterion that stakeholders use to evaluate the organisation's corporate reputation (Moutinho \& Southern, 2010, p. 281). It is imperative for organisations to focus on offering social benefits or risk damaging their corporate reputations and reducing their competitive advantage (Cravens \& Piercy, 2013, p. 118).

If one considers the above-mentioned benefits that can be obtained from implementing CSR initiatives, it becomes clear that executives could, at the outset, profit from guidelines on managing their corporate social responsibility plans more effectively. Secondly, additional principles on the effective management of CSR-driven innovations and reputation management initiatives could then also assist executives in obtaining a competitive advantage.

Thirdly, as part of these guidelines, executives might benefit from insight into the types of social media initiatives they would need to incorporate into their CSR-related plans to truly broaden the competitive edge of the organisation. These guidelines are essential given the fact that according to Jaffrey (2011, p. i), social media has become the new medium of communication in the $21^{\text {st }}$ century and, as a result, must be considered by organisations to ensure they rise above their competitors. Social media allows humans to express their thoughts, ideas and feelings in a new format. Social media statistics, for example, reveal that approximately 350 million people are signed up for Facebook, two new members join LinkedIn every second, and three million blogs are created every month, confirming the popularity of the new communication technology (Bullas, 2012). Social media, as a result, has also had a great impact on organisations, "where they have realised that without a proper plan and social media strategy, they have no chance to stand out in the rapidly changing digital space" (Jaffrey, 2011, p. i).

To date, no academic framework has been compiled that provides assistance to executives on these matters. A framework of this nature, however, could be useful to organisations in surviving and growing their businesses in the modern turbulent business environment. Further research on this matter is therefore, without a doubt, warranted.

\section{PURPOSE}

Against the background provided in the previous section, the purpose of this paper is to offer a theoretical framework on guidelines that organisations could implement to manage their CSR plans and CSR-related initiatives more effectively.

The framework will include actions executives could follow to design and implement their CSR plans more effectively. In addition, principles on the effective management of CSR-driven innovations and reputation management initiatives will also be provided. Thirdly, the framework will focus on guidelines for the types of social media initiatives that would also need to be incorporated into the executive's strategic plan to ensure that the strategy implemented is truly competitive.

Resulting from the theoretical framework, the study will conclude with a number of recommendations that could be further investigated in a follow-on empirical study in order to provide more guidance to executives striving to survive and grow their organisations in the modern turbulent business environment. 


\section{METHODOLOGY}

Secondary sources, such as academic textbooks, research studies previously conducted on the subject matter, internet websites and scientific journals, will be consulted to gain more insight into the research topic and to conduct the literature review of this study.

\section{LITERATURE REVIEW}

The literature review will commence with an overview of the social media concept. Corporate social responsibility, innovation and corporate reputation management will then be explored. The discussion in each section will first focus on a further clarification of the relevant element, secondly on guidelines or principles for effective management, and lastly on types of social media initiatives that would need to be incorporated into the strategic plans to ensure that the organisation is truly competitive.

\subsection{The Social Media Concept}

Social media appears to be the biggest change in society since the industrial revolution and has created a brand new playing field for the human race (Jaffrey, 2011, p. 1). Amid the rising interest in the social media phenomenon, however, it appears that managers and academic researchers alike are not all in agreement regarding a formal definition of social media (Kaplan \& Haenlein, 2010, p. 60). Van der Weel (2009, p. 7), for example, defines social media as "collective goods produced through computer-mediated action on web 2.0 services and platforms", while Pitt, Mills, Chan, Menguc and Plangger (2011, p. 2) describe social media as "media designed to be disseminated through social interaction between individuals and entities such as organisations."

To obtain more clarity on the social media concept, it is necessary to delve into the history and development of this phenomenon. According to Kaplan and Haenlein (2010, p. 60), by 1979 Tom Truscott and Jim Ellis of Duke University had designed a worldwide discussion system, known as "The Usenet", allowing Internet users to communicate public messages. However, the era of social media, as it is known today, most likely started 20 years earlier when Bruce and Susan Abelson created the "Open Diary" (an early social networking site that services a community of online diary writers). Ultimately, the growing availability of high-speed Internet access then contributed to the popularity of the phenomenon, which led to the establishment of many new social networking sites, such as Six Degrees.com (1997), LiveJournal and BlackPlanet (1999), MiGentre (2000), Cyworlds (2001) and Friendster (2002). Collectively, the functionalities of these sites include aspects such as creating personal, professional and dating profiles and identifying friends. From 2003 onwards, social media sites became more specialised, targeting specific audiences. LinkedIn, Visible Path and Xing, for example, focus on business people, Dogster connects strangers based on shared interest, Couchsurfing links travellers to people with couches, and MyChurch connects Christians. Websites focused on media sharing also introduced Flickr (photo sharing), Last.FM (music listening habits) and YouTube (video sharing) (Boyd \& Ellison, 2007, pp. 211-216).

Against this background, social media can be viewed as a group of Internet-based applications that "build on the ideological and technological foundations of Web 2.0 and that allow the creation and exchange of User Generated Content" (Kaplan \& Haenlein, 2010, p. 61). The term Web 2.0, first used in 2004, refers to a platform whereby content and applications are no longer simply designed and published by individuals, but rather are changed on a continuous basis by all users in a participatory and collaborative style (Kaplan \& Haenlein, 2010, pp. 60-61). Korschun and Du (2012, p. 2) confirm that social media is seen as an investment in a networking relationship between organisations and consumers. Users of social media actively participate in conversations and attempt to co-create value. Value is accumulated by the collective actions of all participating stakeholders. Organisations generally engage customers in dialogue by inviting them to actively contribute to the discussion, thereby benefiting from information-rich and often highly personal exchanges. This co-creation can have a significant impact on the expectations of customers as the organisation is now informed about their preferences.

In the new connected millennium, social media can take on many forms and is expected to grow with endless innovation (Jaffrey, 2011, p. 1; Kaplan \& Haenlein, 2010, p. 61). The success of the concept is nested in the fact that the human race loves sharing ideas, engaging in debate and finding friends, allies and lovers. Social media 
platforms include: social networks (personal pages where people connect with friends), blogs (web log, allowing users to post any content), Wikis (communal database that can be edited), podcasts (audio or video files), forums (online discussions of a specific topic), content communities (sharing of content) and microblogging (social networking and bite-sized blogging combined), among others (Jaffrey, 2011, p. 1). Many social media sites are built on these platforms. The most popular social media sites include Facebook, Twitter, WordPress, YouTube and LinkedIn (Jaffrey, 2011, p. 3).

Social media platforms and sites can be of great benefit to organisations. Social media can be used to engage with publics and journalists, be informed of trends, monitor competitors, and market products and services to clients (Cassidy \& Fitch, 2012, p. 12). Jaffrey (2011, p. 2) holds a similar view of social media and believes that it plays an important role in the promotional mix. Social media allows organisations to have conversations with their customers and, at the same time, enables customers to talk to one another. Social media can also be used to predict future occurrences. Asur and Huberman (2010, p. 1), for example, in a formal study, analysed the conversations made on Twitter.com to predict box-office revenues for movies. They discovered that a simple model based on the rate at which tweets on certain topics are generated can outperform market-based predictors.

\subsection{Corporate Social Responsibility}

The true meaning of the corporate social responsibility concept has been the subject of considerable debate and research over the past half-century (Carroll \& Shabana, 2010, pp. 85, 89). Many academics have attempted to provide a formal definition of this phenomenon. In fact, after studying this notion, Dahlsrud (2006, pp. 4, 6) identified 37 definitions that have been formulated to describe the CSR concept. He concluded that even though the definitions have been phrased differently, all of them consistently focused on five dimensions: the environmental dimension (striving for a cleaner environment), social dimension (contributing to a better society), economic dimension (contributing to economic development), stakeholder dimension (behaviour towards stakeholders) and voluntariness dimension (acting in an ethical manner). Accordingly, the absence of one formal definition to describe the CSR concept does not appear to be too problematic, given the fact that organisations could principally focus on the five dimensions, as identified by Dahlsrud (2006, pp. 4, 6), when designing their CSR strategies.

Executing this task successfully, however, appears to be challenging given that organisations need to select an approach that will best assist them in achieving the maximum social benefit from a predetermined budget available for social projects. There are also a limited number of options through which businesses can advance their CSR goals. Organisations must ensure that their CSR strategies are balanced correctly. Philanthropic activities, such as merely making cash donations, are viewed as narrow and self-serving, implemented only to improve the organisation's image. In contrast, however, organisations cannot focus only on socially responsible missions and let go of their objective to generate a profit (Pearce \& Robinson, 2011, pp. 63-66).

Consequently the next section explores guidelines that can be followed to design and implement CSR plans more effectively.

\subsubsection{CSR Management Guidelines}

According to Porter and Kramer (2006), if "corporations were to analyze their prospects for social responsibility using the same frameworks that guide their core business choices, they would discover that CSR can be much more than a cost, a constraint, or a charitable deed - it can be a source of opportunity, innovation, and competitive advantage". This perspective underlines the fact that CSR can have a great influence on marketing strategy choices, specifically with reference to their impact on customer value (Piercy \& Lane, 2009, p. 336). Therefore, organisations need to carefully consider the CSR strategies they add to the marketing agenda to ensure they reap the benefits of opportunity exploitation, innovation and a competitive advantage.

Following are seven considerations to accomplish this task:

1. Organisations first need to ensure that their social responsibility initiatives presented to the public are honest and sincere. There is a positive association between CSR initiatives and the perceived quality and 
purchase intentions of consumers. However, the successful organisation must ensure that their strategies are aligned with the organisation's objectives and values. Customers do not blindly accept social initiatives as sincere and will penalise organisations appearing to be manipulative (Piercy \& Lane, 2009, pp. 340-341). Organisations must be sincerely committed in order to earn a positive reputation among customers. Organisations make the greatest social contribution when they spot an important, long-term policy challenge and take part in its solution over the long term (Pearce \& Robinson, 2011, pp. 67, 71).

2. The introduction of formal social responsibility dimensions to supplier relationships has become the norm of conducting business and has an impact on the selection of new suppliers and the continuation of business relationships with current suppliers. Organisations need to manage their buyer/seller relationships in an ethical manner and should avoid making use of bribes to acquire business contracts (Piercy \& Lane, 2009, p. 341).

3. To ensure CSR strategies are executed effectively, they should not be restricted to predominantly one function of the business, but should instead involve the entire organisation. All functions of the organisation should be aligned, from the human resources function to marketing management (Hildebrand, Sen \& Bhattacharya, 2011, p. 1360). Organisations should also attempt to capitalise on the knowledge and skills within their own resources to introduce new products and services that will benefit society from a CSR perspective (Pearce \& Robinson, 2011, p. 69).

4. According to Pearce and Robinson (2011, pp. 69-70), organisations should focus on contributing to solving larger problems facing society, rather than focusing only on their own small project, which can often be perceived as a "pet project". For example, organisations could join the efforts of businesses globally and plant and preserve trees to address the $\mathrm{CO}_{2}$ emission problem instead of only donating money to a small charity organisation.

5. The relevant country's government support for CSR initiatives undertaken must also be explored. Tax incentives, liability protection, and other measures of support for organisations will all assist in facilitating business participation and add to the success of CSR initiatives (Pearce \& Robinson, 2011, p. 70).

6. The sixth important consideration is that organisations should carefully evaluate the philanthropic activities they wish to pursue. Managers should stay clear of any philanthropic activities that have vague values or methods of establishing pricing. The impact of the activities on the company's reputation should also be calculated and must not be overestimated. Spending limits must be defined, and the initiative should be added to the business's agenda only if the strategy is sound and solid (Sasse \& Trahan, 2007).

7. West, Ford and Ibrahim (2010, p. 462) recommend that organisations also engage with stakeholders to determine their CSR needs and objectives. Important social issues must be identified and integrated into the strategic plan. Values, codes and policies must then be defined and executive responsibility assigned. The CSR strategy must be communicated to the rest of the organisation and training must be provided where necessary. Meaningful measures must be used to evaluate the effectiveness of the strategy implemented.

\subsubsection{Social Media Initiatives Required for Competitive CSR Strategies}

Organisations must also keep in mind that they operate in an environment in which stakeholders are increasingly holding them accountable for the CSR initiatives they have undertaken. The value of the CSR initiatives and the resulting worth of the organisation are positively related if the business is intensely aware of the needs of their customers (Servaes \& Tamayo, 2012, p. ii).

Accordingly, Fieseler, Fleck and Meckel (2009, p. 599) recommend that organisations must not only inform stakeholders of their CSR initiatives, but also engage with them on an online basis to assess their point of view. Social media can assist organisations in identifying the needs and preferences of their customers. Stakeholders can then be encouraged to co-create the CSR strategy of the business. The resulting benefits of this approach include community identification and trust in the business activities performed by the organisation (Korschun \& Du, 2012, pp. 3, 5-6).

Executives wishing to ensure that the organisation is truly competitive would subsequently need to incorporate these social media initiatives into their CSR strategic plans. 


\subsection{Innovation}

The concept of innovation can be described as the generation and implementation of new ideas by human beings who, over a certain period of time, have transacted with other individuals from an institutional perspective (Gebert, 2012, p. 3). Stated differently, Stokes, Wilson and Mador (2010, p. 48) define innovation as "a process of turning ideas into new opportunities for value creation and putting these into widely used practice". Organisations can engage in many types of innovation activities, including new products/services, processes, corporate positioning and business models (Blundel \& Lockett, 2011, p. 67).

Section 1 mentioned that organisations can make use of CSR initiatives as "radar" to identify trends in the market and introduce new innovations. According to MacGregor and Fontrodona (2008, pp. 1-4), the concepts of CSR and innovation have not extensively been discussed in combination in the literature review. However, companies wishing to be successful and innovative today are obliged to examine the social and environmental impact of their operational processes and work well with their customers, suppliers and other stakeholders in designing and developing new products and services. Organisations have no other alternative but to innovate on product levels (adhering to the demands of socially responsible products) and process levels (considering the implications of social responsibility across the entire supply chain). Legislation has also forced organisations to examine their production processes and focus on the recycling of used materials.

Mahlouji and Anaraki (2009, p. 89) explain that due to the partially related characteristics of CSR and innovation, a new theme has emerged in the literature, labelled as "corporate social innovation". The term was first used by Rosabeth Moss Kanter (1999), who believed that organisations should exploit social issues as a learning laboratory for discovering unmet needs and for designing solutions. Since then, practitioners have increasingly adapted this approach to their business strategies. Unilever, for example, approaches corporate social innovation as a method of finding new products and services that address, not only the functional needs of customers for delicious food or clean clothes, but also their greater aspirations as a society (Panapanaan, n.d, p. 4). The core concept of corporate social innovation is to focus on social issues to identify new opportunities while concurrently solving important social needs. However, it appears that only organisations with a very high social performance ranking succeed in approaching CSR as an instrument to drive product innovation (Hockerts \& Morsing, 2008).

Accordingly, the next section explores principles that can be implemented to ensure that CSR-driven innovations are managed more effectively.

\subsubsection{CSR-Driven Innovation Management Principles}

Corporate social innovation can be viewed as a comprehensive management system for accomplishing society improvements on a continuous basis. It requires the life-long commitment of the organisation. Organisations wishing to be successful in their endeavours must ensure that they have a strong visionary leadership which truly believes in the organisation's development strategy as well as its involvement in and empowerment of society (Ningsih \& Ciptono, 2007, p. 96).

According to Hockerts and Morsing (2008), organisations wishing to follow a CSR-driven innovation strategy must ensure that knowledge structures are created which stem from investments in corporate social performance. CSR management and communication tools can facilitate the corporate learning process (Hockerts, Midttun, Halme, Sweet, Davidsson \& Nurmi, 2009, p. 9).

Commercially-driven organisations could also establish partnerships with social entrepreneurs to promote social innovation. These relationships could lead to a number of mutual benefits for both organisations. Firstly, new opportunities for training, mentoring and leadership development would be presented. Low-cost and improved service efficiency and service delivery could also be achieved. Thirdly, new creative ways of operating to address difficult challenges and prospects could also be designed. Fourthly, more effective relationships with key stakeholders benefiting directly and indirectly from the partnerships could be established. Lastly, the initiative could also lead to the facilitation of a stable society (Panapanaan, n.d., p. 9). 
The first step in the innovation process, however, usually entails searching the environment for warning signs of threats or opportunities for change. Organisations then need to consult their strategic plans and decide to which of the signals they will react. Thirdly, resources must be obtained to facilitate the response, and, lastly, the action plan must be implemented. The success of the organisation is determined by its ability to deal with the extra commitment or new course required (Stokes et al., 2010, p. 57). Pearce and Robinson (2011, pp. 373-376) are of the opinion that meaningful innovation is further dependent on whether the organisation has a clear view on the customer's perspective of the quality required. Organisations must build relationships with customers, and innovations must be designed with a customer orientation in mind. An atmosphere of total involvement must be facilitated.

Social media presents an ideal platform to assist organisations in accomplishing this task. The next section will explore this matter further and will focus on social media initiatives that would need to be incorporated into the innovation plan to ensure that the organisation is truly competitive.

\subsubsection{Social Media Initiatives Required for Competitive Innovation Strategies}

Social media presents an ideal platform to assist organisations in acquiring the necessary information from their customers. According to Gebert (2012, pp. 4-5), an increasing number of organisations are realising that social media can be used as a tool to assist them in conducting research and developing service innovations. Social media enhances information and knowledge contribution and is the stage upon which community-based research and development service innovations are coordinated. Social media technology also assists organisations in identifying customer anxieties, needs and trends pertaining to innovations and can lead the way to further enhancements and innovations. Customers have the best knowledge of their values, opinions and emotions. They know what they want and should be monitored on a continuous basis. Information can, in addition, be obtained from customers at a low cost (Mustonen, 2009, p. 24).

According to Archer (2012, p. 4), customers who are involved in the creation of innovations through social media and who are also then responsible for the consumption thereof, are known as prosumers. The term prosumer was first used by futurist author Alvin Toffler in his book Third Wave, which was published in 1999. Prosumers are generally viewed as consumer activists between 22 and 42 years old who are involved in the design and manufacturing of products and services (Konczal, 2010, p. 4). The main reasons for the birth of the prosumer are that people became weary of using the same uniform products and working in the same specialised domains where they were not able to provide their own signature to a single item. Consequently, the prosumer is responsible for the infringement of the mass production barrier and rather follows the ABDE rules - anyplace, brand communication, discovery and experience. Virtual prosumers have no limits in articulating their creativity and are known as knowledgeable consumers, digital users who make use of technologies for contributing to the product or service conception, design and execution, and who have a great influence on their social networks (Izvercianu \& Seran, 2012, p. 5.47).

Prosumerism is driven by connectivity and interactivity and facilitates development. Prosumers enjoy evaluating options and wish to make smart decisions. The right decision, however, is dependent on the context and the individual but, in general, relates to being well-informed, being aware of available options, and considering the opinions of other individuals. Prosumers prefer lower product prices, unless they are convinced they will receive value for money. Value, in return, is perceived as good customer service, design or brands (Konczal, 2010, pp. 4-7).

Consequently, prosumers are very selective in their choices. They have high expectations in terms of quality and time frame associated with delivery. Prosumers select products on the basis of information, and they seek digital processes. Place and distance are not important to them, and they attempt to avoid travelling to shopping centres. Web communication is preferred. Prosumers are likely to make use of broadband and new digital services. Service providers, however, may be switched should they be in a position to receive better service from another provider (Konczal, 2010, pp. 4-7).

It is imperative that organisations wishing to prosper make a sound attempt to win the hearts and minds of prosumers. Prosumers are the buyers and sellers of the future. Organisations must adapt and discover new methods 
to draw them to their sites and platforms. Organisations that cannot adapt their approaches will not survive as a result of shifting market demands and powerful and flexible competitors (Izvercianu \& Seran, 2012, p. 5.52).

Using social media applications to engage with prosumers is, by no means, a ready-tailored package. Applications change rapidly and there are always new possibilities and applications that can be explored. Organisations, for example, can make use of blogs and approach topics from several angles, such as new developments or new products and services. Discussion forums can also be used to collect information for product innovation. Solutions from participants can be presented to the community through verbal description or visual designs. MySpace allows organisations to create a group dedicated to a certain business or product, add information and collect feedback (Mustonen, 2009, pp. 23-24). Cateora (2007, pp. 230-231) believes that the systematic analyses of these platforms assist organisations in obtaining more insight into the opinions of the customers on certain products and services.

Secondly, Gebert (2012, p. 5) argues that it is imperative for organisations to focus on McKinsey's LEAD approach to allow for the effective undertaking of innovation in the business world, while making use of social media. The process first entails listening to the conversations taking place on social media pages. Organisations need to monitor social commerce behaviour in the category they wish to explore, as a starting point, to identify great opportunities. Secondly, organisations then need to determine their action plan and start experimenting. In the third step, ideas must be applied. The most favourable concept must be selected and improved. Lastly the development of the new concept should then be continuously monitored and improved, using insights obtained from social media discussions (Gebert, 2012, pp. 5-6).

Thirdly, according to Martini, Massa and Testa (2012, p. 2), there is still concern that customers might not make creative contributions, and the type of social media that will be most suitable for a specific innovation effort must also be determined. The problem of obtaining creative ideas from customers, however, could potentially be resolved by making use of idea competitions. Elmquist, Fredberg and Ollila (2009, p. 332) mention that these competitions can release customer creativity through making use of hidden knowledge and customer preferences. Stahlbrost (2012, pp. 55-56) further highlights the fact that a specific set of criteria can be considered when selecting social software to employ for user engagement. These criteria include the nature of the community using a specific social media as well as their familiarity with the technology and the user-friendliness of the application.

Fourthly, prosumers prefer organisations that entertain them. Organisations must therefore create an entirely new buying experience for prosumers and focus on customer personalisation and buying convenience. To accomplish this task, organisations must offer a bundled experience with a rich mix of service offerings, customercentric sales experience, multi-channel customer interactions, and measures to deliver the service quickly and efficiently (Konczal, 2010, pp. 6-7). Prosumers must be offered product features that allow them to play around and become innovative. However, standard marketing strategies for highly involved consumers must be designed around the requirements of the Internet. Prosumers must be provided with the functionality to alter product designs on the Internet to enable them to present new innovative product ideas (Hemetsberger, 2003, pp. 28-29).

\subsection{Corporate Reputation Management}

Jacob (2012, p. 263) defines the reputation of an organisation as a stakeholder's overall assessment of an organisation over a certain period of time. The evaluation is based on the stakeholder's experience of the visible conduct of the organisation as well as the image perceived from their communication and positioning against competitors. Moutinho and Southern (2010, p. 271) confirm that "in the corporate world, reputation is seen as a major element of an organisation's provenance alongside and included in financial performance and innovation". It can be viewed as a collective representation of a number of stakeholders' images of an organisation that are formed over a certain period. It is also connected to the identity of the organisation as well as its performance and the manner in which stakeholders respond to this conduct (Moutinho \& Southern, 2010, p. 271).

In academia, as well as in the business community, an organisation's reputation is viewed as one of the most valuable intangible assets due to the fact that it is very difficult to duplicate by competitors. Corporate reputation can aid organisations in achieving a prolonged competitive advantage which, in return, will not only 
improve a customer's confidence in products, services and advertising claims, but will also lower their doubts pertaining to purchasing transactions completed (Schwaiger \& Zhang, 2009, p. 2; Issa, 2011, p. 13). Customers generally aim to benefit by association and a good corporate reputation will add to the value of the customer relationship through the assurance that it is safe to conduct business with the organisation and that the customer's status is not at risk. The reputation of the organisation also influences investors, capital markets, and the ability of the organisation to attract talented employees (Cravens \& Piercy, 2013, p. 119). It is therefore imperative for organisations to focus on building and managing a strong corporate reputation. A loss of reputation could severely weaken the operating conditions of the organisation and may result in poor financial performance (Aula, 2010, $\mathrm{p}$. 45).

Section 1 mentioned that corporate social responsibility can further be used as a strategic tool to manage the reputation of the organisation (Jacob, 2012, p. 263). While some organisations do attempt to focus on social responsibility strategies to improve their reputation, it appears, however, that they are not doing enough to sustain their reputation over time. Great corporate responsibility initiatives are not communicated effectively to the relevant stakeholders (Stephen, 2009, p. 1). Furthermore, performing this task successfully appears to be challenging given the fact that organisations cannot explicitly admit that they supported an event to improve their corporate reputation. An organisation's reputation is also formed by the perceptions of individuals who might not all share the same opinion of the organisation (Walter, 2012).

Consequently, the next section will explore principles that can be implemented to ensure the effective management of CSR-driven reputation management initiatives.

\subsubsection{CSR-Driven Reputation Management Principles}

Corporate reputation is built through determining the needs and commitments of the organisation towards its stakeholders and then ensuring that an effective communication strategy is implemented to achieve the desired results (Rojas, 2010, p. i).

Walter (2012) provides the following four guidelines that organisations could follow to more effectively communicate their CSR initiatives and improve their corporate reputation:

1. Organisations must make certain that stakeholders are aware of the CSR initiatives that were undertaken. The message, however, must be communicated in a sensitive manner. Organisations should not provide too much information and risk being perceived as a corporate hypocrite.

2. Organisations must ensure they have a positive image among their customers before attempting to further enhance their corporate reputation. Customers will not take organisations with a poor image seriously.

3. The CSR programme to be implemented must be credible. Customers who trust the organisation will also need to believe the message communicated to them.

4. The CSR programme must be transparent and explain the benefits that the organisation will gain from implementing the strategy. Customers will not support organisations who claim that they follow a CSR strategy to benefit only the community.

According to Reddiar, Kleyn and Abratt (2012, p. 29), it is the responsibility of the board to manage the reputation of an organisation as these individuals can be viewed as the custodians of the corporate reputation. Executing this task successfully in the modern environment of online communication, however, might be challenging. Due to the interactive nature of social media, unsatisfied customers can use this medium to voice their disappointment and cause severe damage to the reputation of the organisation. According to Aula (2010, p. 43), for example, United Airlines refused to compensate a passenger for damaging his guitar. The passenger, a professional musician, eventually composed a song about the incident (United Breaks Guitars) and posted the video on YouTube. Within a few days, the song was viewed by millions of people and led to widespread coverage on other blogs, forums and websites, as well as in printed media and on television. Aula (2010, p. 43) concludes that the incident threatened both the reputation and the business of the organisation. Owen and Humphrey $(2009$, p. 4) further postulate that the damage caused the recipient of a social media attack can be permanent. A twice-yearly survey conducted by Nielsen Global Online revealed that $90 \%$ of customers tend to trust "completely" or "somewhat" the 
recommendations of people they are acquainted with (Letia \& Slavescu, 2011, p. 2). A carefully designed corporate reputation could thus easily be destroyed by the comments uploaded on social media by an unsatisfied customer, who is then believed by his or her followers. Organisations must create the impression online that they are credible and reliable. This, in turn, will lead to customer satisfaction and the preservation of the reputation of the organisation (Issa, 2011, p. 34).

Consequently, the next section will focus on social media initiatives that would need to be incorporated into the corporate reputation management plan to ensure that the organisation is truly competitive.

\subsubsection{Social Media Initiatives Required for Competitive Corporate Reputation Strategies}

The customers' perception of the reputation of the organisation is affected online by the message delivered, the extent and quality of its exposure, as well as the medium in which the message is received. Organisations wishing to influence online messages must ensure that they are perceived as a credible source. Source credibility is required to communicate messages effectively but often depends on the receiver's perception of the sender's reliability and knowledge. Organisations must ensure that they are trustworthy and competent in their dealings (Issa, 2011, p. 31).

Organisations communicating to their target audiences online may perform this task using dialogues or monologues. Conversations with customers, however, are more suitable for managing online reputations. Wellmanaged and orchestrated online conversations could assist organisations in fostering and maintaining a good presence, reputation and brand image (Jones, Temperley \& Lima, 2009, p. 930).

Employees also play an important role in establishing a favourable online reputation for the organisation. According to Rokka, Karlsson and Tienari (2012, p. 39), the most successful organisations and brands task their employees to support the organisation's brand image and presence online. They do not believe in restricting the employee's access to social networks at work and view every member of the organisation as a potential brand ambassador in the social media environment.

Organisations may also make use of a professional reputation management firm to evaluate online conversations and design an appropriate response. BrandsEye, for example, is a reputation management firm in South Africa that makes use of sentiment analysis to track online conversations. These conversations are then analysed and the relevance to the organisation identified. An appropriate strategy can be developed to improve the organisation's corporate image (Bouwer, 2012, p. 15).

Finally, it is also important for an organisation to follow good ethical standards when making use of social media technologies (Toledano \& Wolland, 2011, p. 43). Good ethical standards assist in forming a solid foundation for an attractive corporate reputation. Ethical practices help to create and sustain trust with customers. Management must therefore be proactive in their endeavours to establish an ethical climate within the organisation (Cravens \& Piercy, 2013, p. 119).

\section{FINDINGS}

\subsection{Observations and Managerial Implications}

Following the theoretical discussion in the previous section, it is now possible to point out a number of observations and resulting managerial implications for organisations.

In the modern turbulent business environment, where customers are more informed and demand corporate responsibility, executives are obliged to identify new sources of competitive advantage in order to survive and grow their businesses over the long term. It further became evident from the literature review that organisations could focus on CSR initiatives as a starting point to assist them in obtaining a competitive edge.

Customers are more likely to conduct business with organisations that endorse positive societal change. As such, executives following this trend would need to approach their CSR initiatives as a source of opportunity to win 
the hearts and minds of their customers. Funds should not merely be allocated to minor charity events to promote the image of the organisation. Executives should instead demonstrate sincere commitment and focus on solving larger problems facing society. Stakeholders can provide valuable information in this regard, and organisations should engage with them to determine their CSR needs and objectives. In addition, relationships with buyers and sellers must also be conducted in an ethical manner, and all functions of the business must be aligned to ensure that the initiative is executed in an efficient manner and value is added to society. The impact of the initiative on the organisation's reputation, as well as relevant government support, must also be considered.

These findings imply that regular meetings should be held with relevant stakeholders in order to identify social demands and CSR projects that can make a valuable contribution to society. Organisations can also engage with their stakeholders online to determine their point of view and encourage them to co-create the CSR strategy of the business. Organisations must further define their ethical codes and standards and motivate employees to act truthfully in all situations at all times. Ethical performance must also be monitored and corrective procedures and training provided where required. Employees must be encouraged and provided with the opportunity to invest their knowledge and skills in the CSR initiative and to introduce services that will benefit society. All the functions in the business, however, must be aligned and operate as a unit to successfully execute the CSR project.

Regular interactions with stakeholders on CSR initiatives can further assist executives in identifying trends in the market and introduce new innovations. Social issues can be exploited to discover unmet needs and design appropriate solutions. The successful execution of corporate social innovation, however, is dependent on whether organisations have a strong visionary leadership which truly believes in the organisation's development strategy as well as its involvement and empowerment in society. The environment must be searched for warning signs of threats or opportunities for change. Decisions must be made regarding the signal to which the organisation will react, and knowledge structures must be created that stem from investments in corporate social performance. Appropriate resources must be allocated to fund the project and organisations could consider establishing partnerships with social entrepreneurs to assist them in promoting and delivering social innovation.

In light of the above-mentioned actions required for corporate social innovation, the resulting implication for executives is to ensure that they are sensitised to the needs and ideas of their customers. Suitable questions must be asked to discover unmet needs and potential profitable CSR innovations. Prosumers must be attracted through social media platforms and involved and entertained to draw on their creativity and ideas. Executives can make use of the principles discussed in Section 4.3.2 to accomplish this task. The organisation must further live by the vision of empowering society and must conduct a thorough analysis of the environment to identify opportunities. Opportunities should be evaluated based on the organisation's ability to deliver superior value as well the social contribution that can be made to society. Staff must also be well trained and motivated to contribute to the innovation and deliver superior value. In the absence of skilled resources, organisations could network with social entrepreneurs to find solutions for social problems. According to Blundel and Lockett (2011, p. 93), however, the management of networking relationships can be very challenging. Executives need to consider carefully the types of businesses they would wish to involve in their ventures, the resources they might contribute, as well as the quality of the interactions that might occur. Decisions must then be made that will benefit both the organisation as well as society.

Given the fact that CSR can also be used as a strategic tool to manage the reputation of the organisation, executives would need to ensure that the message is communicated in an appropriate manner that will not create the impression that the organisation is only seeking publicity. Executives should therefore not provide too much information and first ensure they are favoured by their customers before attempting to further enhance the corporate reputation. A credible programme must be followed and the benefits to both the organisation and the customers must be clearly explained. Conversations with customers online are essential to manage online reputations. Customers, however, would need to perceive the organisation as a credible source. Employees can also be used to act as brand ambassadors in the social media environment, provided that ethical practices are followed. The success of these initiatives could then be monitored by a professional reputation management firm and the necessary adjustments made to ensure that the organisation's corporate reputation management initiatives are executed effectively. 
The implications of these findings are that organisations would first need to focus on winning the respect and favour of their customers. They need to conduct business in an ethical manner and create favourable brand messages that are well received by their customers. Only once a positive image has been established should attempts be made to communicate the CSR initiatives of the organisation. A highly skilled marketing team should then be used to compile a well-crafted message that will convince customers that the organisation values their social ideas and adheres to their wishes to benefit society. Employees must also be well trained and motivated to engage in meaningful conversations with customers online and to further build the corporate reputation. Finally, provided that the board can be viewed as the custodians of the corporate reputation, it would be their task to manage the quality of the initiatives undertaken and, through their appropriate actions, further contribute to the positive corporate reputation of the organisation.

\subsection{Theoretical Framework}

Following the observations and managerial implications highlighted in the first part of Section 5, it is now possible to propose the theoretical framework of this study and suggest guidelines that organisations could implement to manage their CSR plans and CSR-related initiatives more effectively. The proposed framework is displayed in Figure 1. 


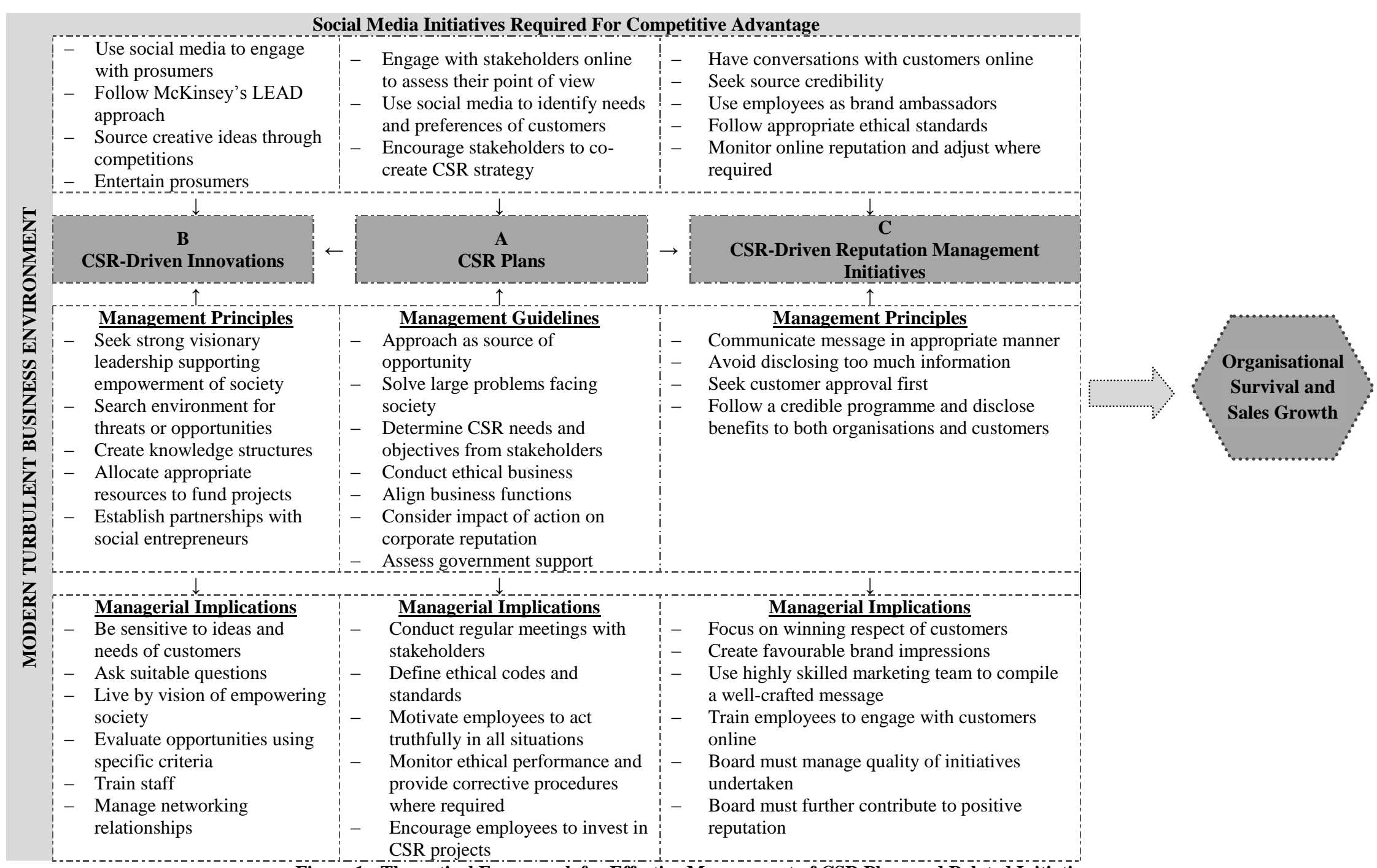

Figure 1: Theoretical Framework for Effective Management of CSR Plans and Related Initiatives 


\subsubsection{Modern Turbulent Business Environment}

The first block on the left side of the diagram reflects the turbulent business environment in which organisations in the new connected millennium need to function, an environment of which social media platforms form an integral part, characterised by informed customers demanding corporate behaviour that is socially responsible.

\subsubsection{CSR Plans}

The CSR plans block (Block A) is situated in the centre of the diagram, indicating that organisations could focus on CSR initiatives as a starting point to assist them in obtaining a competitive advantage. A number of management guidelines can be followed to aid the executive team in designing and implementing their CSR plans more effectively. These guidelines are summarised in the block directly below Block A. Organisations, however, would also need to pay attention to the managerial implications of the proposed guidelines that were discussed in Section 5.1 and that are summarised in the block directly below the management guidelines. These implications provide more insight into the practical steps that executives would need to follow to proficiently implement the management guidelines provided.

\subsubsection{CSR-Driven Innovations}

An arrow points from the CSR Plans block to the CSR-Driven Innovation block (Block B), indicating that interactions with stakeholders on CSR initiatives can further assist executives in identifying trends in the market and introduce new innovations. Social issues can be exploited to discover unmet needs and design appropriate solutions. Executives would also need to follow a set of principles to assist them in managing the CSR-driven innovations effectively. These principles are summarised in the block directly below Block B. The managerial implications of the proposed principles that were discussed in Section 5.1 are then summarised in the block directly below the list of principles. Similar to the previous discussion, these implications provide more insight into the practical steps that executives would need to follow to proficiently implement the management principles provided.

\subsubsection{CSR-Driven Reputation Management Initiatives}

CSR can be used as a strategic tool to manage the reputation of the organisation (indicated by the arrow pointing from the CSR Plans block to the CSR-Driven Reputation Management Initiatives block - Block C).There is also a list of management principles that would need to be followed to implement the reputation management initiatives successfully. These principles, as well as their managerial implications, are then summarised in the two blocks below Block $\mathrm{C}$ and need to be pursued to ensure that positive and credible perceptions of the organisation are created in the minds and hearts of customers.

\subsubsection{Social Media Initiatives Required for a Competitive Advantage}

A number of social media initiatives overarch Blocks A to C. Executives would also need to pay attention to these initiatives when implementing their CSR and related plans in order to ensure that the strategies implemented are truly competitive.

\subsubsection{Organisational Survival and Growth}

Ultimately, the successful management of the CSR plans and related initiatives could assist organisations to survive and grow their businesses in the turbulent business environment.

\section{CONCLUSIONS AND RECOMMENDATIONS}

In the new connected millennium, the intensification of competition, greater demands from customers, and social media challenges have created pressure for organisations to perform and survive. Executives are left with no alternative choice but to find new avenues to gain a competitive advantage and grow their businesses over the long term. 
Organisations could focus on CSR initiatives as a starting point to assist them in obtaining a competitive advantage. Regular interactions with customers would then further aid executives in identifying new corporate social innovation initiatives that could benefit society. The effective communication of CSR plans might also help organisations in building a positive reputation and persuade customers that they are truly caring about the world.

Consequently, to assist executives in managing their CSR plans and CSR-related initiatives more effectively, this paper has proposed a theoretical framework that can serve as a guideline for organisations wishing to obtain a competitive advantage. The framework includes actions that executives could implement to design and implement their CSR plans more effectively. In addition, principles for the effective management of CSR-driven innovations and reputation management initiatives are also provided. The framework also focuses on guidelines for the types of social media initiatives that would need to be incorporated into the executive's strategic plan to ensure that the strategy implemented is truly competitive.

The author recommends that further research be conducted on this matter to explore the proposed framework in more depth. An empirical investigation is needed to determine the significance of the management principles and managerial guidelines highlighted. The success of the organisation could, for example, be monitored before and after the guidelines have been implemented to measure the true effect on its profitability. It would also be interesting to determine additional social media initiatives that could be implemented to further assist the organisation in obtaining a competitive advantage.

To conclude, the research reported in this paper represents a preliminary investigation into guidelines that can be implemented to manage CSR plans and CSR-related initiatives more effectively. The findings of the study, although limited in scope, contribute to the improvement of organisational behaviour within the socially responsible environment and could lead to greater profitability over the long term.

\section{AUTHOR INFORMATION}

Dr. Estelle van Tonder is Head of Department in the Faculty of Management and Leadership at Milpark Business School. She holds a DCom degree in Marketing Management from the University of Pretoria and has also completed a Postgraduate Diploma in Financial Planning with the University of the Free State. Estelle has secured extensive experience in the financial services sector in the capacities of Broker Consultant, Senior Project Manager, Training Manager and Marketing Manager, before she became and academic in 2009. Her research interests include strategic marketing, customer relationship management and contemporary marketing management issues. She has delivered papers at national and international conferences and also published in national and international journals. She acts as a referee for various conferences and journals, is a member of the Marketing Association of South Africa and is also the Editor in Chief of the International Business and Economics Research Journal. E-mail: estellev@milpark.ac.za (Corresponding author)

Mornay Roberts-Lombard is Professor of Marketing in the Department of Marketing Management at the University of Johannesburg in South Africa. He has published widely in South African and international journals in the fields of Relationship Marketing, Customer Relationship Management (CRM) and Services Marketing. He is furthermore also a public speaker in his field and manages his own blog on CRM in South Africa. He is a devoted teacher and has a passion for the Marketing field. E-mail: $\underline{\text { mornayrl@uj.ac.za }}$

\section{REFERENCES}

1. Archer, C. (2012, November). The borderless world according to bloggers: Prosumers, producers, creatives and post-consumers tell their side of the communications story. Paper presented at the World Public Relations Forum, Melbourne, Australia.

2. Asur, S., \& Huberman, B. A. (2010). Predicting the future with social media. Retrieved from http://arxiv.org/pdf/1003.5699.pdf

3. Aula, P. (2010). Social media, reputation risk and ambient publicity. Strategy and Leadership, 38(6), 4349. 
4. Barnea, A., \& Rubin, A. (2005). Corporate social responsibility as a conflict between shareholders. Retrieved from http://apps.olin.wustl.edu/jfi/pdf/csr.conflict.pdf

5. Blundel, R., \& Lockett, N. (2011). Exploring entrepreneurship: Practices and perspectives. New York, NY: Oxford University Press.

6. $\quad$ Bouwer, C. (2012). Do you care what they're whispering? Strategic Marketing, 4, 14-18.

7. Boyd, D. M., \& Ellison, N. B. (2007). Social network sites: Definition, history, and scholarship. Journal of Computer-Mediated Communication, 13(1), 210-230.

8. Bullas, J. (2012). The latest 27 social media facts, figures and statistics for 2012 - infographic. Retrieved from http://www.jeffbullas.com/2012/11/28/the-latest-27-social-media-facts-figures-and-statistics-for2012-infographic/

9. Carroll, A. B., \& Shabana, K. M. (2010). The business case for corporate social responsibility: A review of concepts, research and practice. International Journal of Management Reviews, 12(1), 85-105.

10. Cassidy, L., \& Fitch, K. (2012, November). Beyond the catwalk: Exploring social media use in public relations in the Australian fashion industry. Paper presented at the World Public Relations Forum,

Melbourne, Australia.

11. Cateora, G. (2007). International marketing. New York, NY: McGraw-Hill.

12. Cravens, D. W., \& Piercy, N. F. (2013). Strategic marketing. Singapore: McGraw-Hill.

13. Dahlsrud, A. (2006). How corporate social responsibility is defined: An analysis of 37 definitions. Corporate Social Responsibility and Environmental Management, 15, 1-13.

14. Elmquist, M., Fredberg, T., \& Ollila, S. (2009). Exploring the field of open innovation. European Journal of Innovation Management, 12(3), 326-345.

15. Fieseler, C., Fleck, M., \& Meckel, M. (2009). Corporate social responsibility in the blogosphere. Journal of Business Ethics, 91, 599-614.

16. Gebert, M. (2012). Innovation from use of new media for sharing ideas and business. Retrieved from http://www.crowdsourcing.org/index.php/document/innovation-from-use-of-new-media-for-sharing-ideasand-business-/18083

17. Hemetsberger, A. (2003). When consumers produce on the Internet: The relationship between cognitiveaffective, socially based, and behavioural involvement of prosumers. The Journal of Social Psychology, 133.

18. Hildebrand, D., Sen, S., \& Bhattacharya, C. B. (2011). Corporate social responsibility: A corporate marketing perspective. European Journal of Marketing, 45(9), 1353-1364.

19. Hockerts, K., Midttun, A., Halme, M., Sweet, S., Davidsson, P., \& Nurmi, P. (2009). CSR-driven innovation: Towards the social purpose business. Retrieved from http://www.samfundsansvar.dk/graphics/Samfundsansvar.dk/csrinnovation/Dokumenter/csr-direport_final.pdf

20. Hockerts, K., \& Morsing, M. (2008). A literature review on corporate social responsibility in the innovation process. Copenhagen, Hovedstaden: Copenhagen Business School (CBS), Center for Corporate Social Responsibility.

21. Issa, M. (2011). Preserving corporate reputation in the social media era. (Master's thesis, Iowa State University).

22. Izvercianu, M., \& Seran, S. (2012). Company identity and business models in the virtual world of prosumer collaboration. Fascicle of Management and Technological Engineering, xi(xxi), 5.47-5.52.

23. Jacob, C. K. (2012). The impact of financial crisis on corporate social responsibility and its implications for reputation risk management. Journal of Management and Sustainability, 2(2), 259-275.

24. Jaffrey, J. (2011). Social media and marketing. (Bachelor's thesis, School of Information and Communication Technology, Sweden).

25. Jones, B., Temperley, J., \& Lima, A. (2009). Corporate reputation in the era of Web 2.0: The case of Primark. Journal of Marketing Management, 25(9/10), 927-939.

26. Kaplan, A. M., \& Haenlein, M. (2010). Users of the world, unite! The challenges and opportunities of social media. Business Horizons, 53, 59-68.

27. Konczal, J. (2010). Identifying, knowing, and retaining your customers: The "prosumer". Retrieved from http://downloads.lightreading.com/thecmosite/SC0529_Prosumer_WP.pdf

28. Korschun, D., \& Du, S. (2012). How virtual corporate social responsibility dialogs generate value: A framework and propositions. Journal of Business Research, 1-11. 
29. Letia, I. A., \& Slavescu, R. R. (2011). Decision making based on trust and reputation in Ecommerce. Retrieved from http://2011.icore.name/file_download/8/paper_8.pdf

30. Louw, L., \& Venter, P. (2012). Strategic management: Developing sustainability in Southern Africa. Cape Town, Western Cape: Oxford University Press.

31. MacGregor, S. P., \& Fontrodona, J. (2008). Exploring the fit between CSR and innovation. Retrieved from http://www.iese.edu/research/pdfs/DI-0759-E.pdf

32. Mahlouji, H., \& Anaraki, N. K. (2009). Corporate social responsibility towards social responsible innovation: A dynamic capability approach. International Review of Business Research Papers, 5(6), 185194.

33. Martini, A., Massa, S., \& Testa, S. (2012). The role of social software for customer co-creation: Does it change the practice for innovation? International Journal of Engineering Business Management, 4(40), 110 .

34. Moutinho, L., \& Southern, G. (2010). Strategic marketing management. Andover, Hampshire: Cengage Learning.

35. Mustonen, P. (2009). Social media - a new way to success? Turku, Western Finland: Turku School of Economics.

36. Ningsih, D. A., \& Ciptono, W. S. (2007). Going beyond corporate social responsibility: The critical factors of corporate social innovation - an empirical study. Journal Akuntansi \& Manajemen, 18(2), 87-98.

37. Owen, R., \& Humphrey, P. (2009). The structure of online marketing communication channels. Journal of Management and Marketing Research, 1-10. Retrieved from http://www.aabri.com/manuscripts/09135.pdf

38. Panapanaan, V. (n.d.). Social innovations and its potential for business, investment and partnerships in Finland. Retrieved from gin.confex.com

39. Pearce, J. A., \& Robinson, R. B. (2011). Strategic management. New York, NY: McGraw-Hill.

40. Piercy, N. F., \& Lane, N. (2009). Corporate social responsibility: Impacts on strategic marketing and customer value. The Marketing Review, 9(4), 335-360.

41. Pitt, L., Mills, A. J., Chan, A., Menguc, B., \& Plangger, K. (2011, June). Using Chernoff faces to portray social media wine brand images. Paper presented at the 6th AWBR International Conference, Bordeaux, France.

42. Porter, M. E., \& Kramer, M. R. (2006). Strategy and society: The link between competitive advantage and corporate social responsibility. Harvard Business Review, 84(12), 78-92.

43. Reddiar, C., Kleyn, N., \& Abratt, R. (2012). Director's perspectives on the meaning and dimensions of corporate reputation. South African Journal of Business Management, 43(3), 29-39.

44. Rojas, L. M. M. (2010). A study of the relationship between corporate social responsibility and reputation management: A case study analysis of a Mexican restaurant chain. (MBA thesis, National Taiwan University of Science and Technology, Taipei).

45. Rokka, J., Karlsson, K., \& Tienari, J. (2012). Employees, social media, and corporate reputation: What can financial service providers learn from other sectors? Business \& Economy, 1, 39-48.

46. Sasse, C. M., \& Trahan, R. T. (2007). Rethinking the new corporate philanthropy. Business Horizons, 50, 29-38.

47. Schwaiger, M., \& Zhang, Y. (2009). What drives corporate reputation in consumers' minds? A comparative study between China and Western countries. Retrieved from http://www.duplication.net.au/ANZMAC09/papers/ANZMAC2009-390.pdf

48. Servaes, H., \& Tamayo, A. (2012). The impact of corporate social responsibility on firm value: The role of customer awareness. Retrieved from http://faculty.london.edu/hservaes/ms2013.pdf

49. Stahlbrost, A. (2012). Challenges with social media for user involvement. Retrieved from http://tapironline.no/fil/vis/1090

50. Stephen, E. (2009). Corporate reputation. How strategic community initiatives can build and sustain corporate reputation. Business Community Ireland, Autumn 2009.

51. Stokes, D., Wilson, N., \& Mador, M. (2010). Entrepreneurship. Andover, Hampshire: Cengage Learning.

52. Toledano, M., \& Wolland, L. F. (2011). Ethics 2.0: Social media implications for professional communicators. The International Journal of Communication on Ethics, 8(3/4), 43-52.

53. Van der Weel, A. T. (2009). The alignment of web 2.0 and social media with business strategy. (Bachelor's thesis, University of Amsterdam, Amsterdam). 
54. Walter, B. L. (2012). Does corporate social responsibility really contribute to reputation? Retrieved from http://blwalter.com/wp-content/uploads/2012/11/2012-10-19-IRMC-Presentation_BLWalter.pdf

55. West, D., Ford, J., \& Ibrahim, E. (2010). Strategic marketing: Creating competitive advantage. New York, NY: Oxford University Press. 